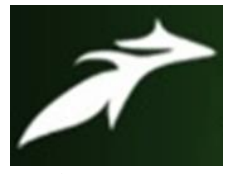

Prerna Kujur et al, International Journal of Advances in Agricultural Science and Technology,

Vol.8 Issue.9, September-2021, pg. 9-14

ISSN: 2348-1358

Impact Factor: 6.057

NAAS Rating: 3.77

\title{
Socio-Economic Condition and Constraints faced by Tea Garden Women Workers in Chhattisgarh
}

\author{
Prerna Kujur* \\ M.Sc. Ag.(Agricultural Extension and Communication) \\ Syed H. Mazhar** \\ (Associate Professor), Department of Agricultural Extension and Communication, SHUATS (Prayagraj) \\ Jahanara*** \\ (Head and Associate Professor), Department of Agricultural Extension and Communication \\ *Email id: kujurprerna96@gmail.com \\ DOI: 10.47856/ijaast.2021.v08i9.002
}

ABSTRACT: The present study was conducted in Jashpur district of Chhattisgarh to find out the socio-economic condition of women tea growers, to find out the constraints faced by them and seek suggestions to improve better working conditions. A total of 120 respondents were selected randomly for the present study. The data was collected through a pre-structured interview schedule and later appropriate statistical analysis was done to find out meaningful result. The result showed that the women tea growers found that there was improper sanitation facility inside the tea garden. They suggested that improved sanitation facility and social mobility could help them to improve better working environment.

KEYWORDS: Socio economic, women workers, tea garden, constraints, suggestions.

\section{INTRODUCTION}

India is the second-largest producer of tea after China. Tea plantations were introduced to the country by the British, during the colonial regime. Over the years, Indians started producing different varieties of teas.

Tea is an aromatic beverage commonly prepared by pouring hot or boiling water over cured leaves of the Camellia sinensis, an evergreen shrub native to Asia. After water, it is the most widely consumed drink in the world. 


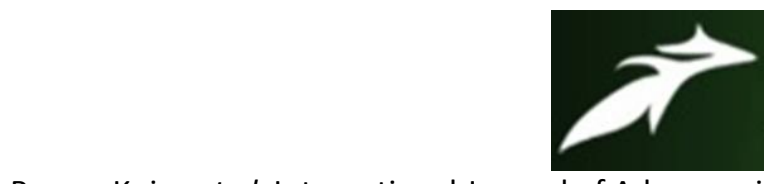

Prerna Kujur et al, International Journal of Advances in Agricultural Science and Technology,

Vol.8 Issue.9, September-2021, pg. 9-14

ISSN: 2348-1358

Impact Factor: 6.057

NAAS Rating: 3.77

Chhattisgarh is emerging as a potential destination for tea plantation. Apart from Surguja, Jashpur and Balrampur districts also have favorable pockets for taking up the crop. The state's Agricultural Research Center has conducted a detailed study in these pockets and have recommended that the climate of north Chhattisgarh is most suitable for tea.

Chhattisgarh is currently ranked $17^{\text {th }}$ in the country on tea production, which was started in the state by Sogara Ashram in Surguja some six years ago. A processing unit was also set up in the Ashram. The project prompted the forest to start growing tea as well and set up a tea nursery in the district.

Jashpur with green forests is doing tea farming in Chhattisgarh. The matter of Tea Garden in Jashpur is now certified. This thing has been proved now. The success of a 20-acre tea estate developed in Sarudih has given the district administration the impetus to take this campaign forward.

\section{RESEARCH METHODOLOGY}

The present study was conducted in Jashpur district of Chhattisgarh state. There were 8 blocks in Jashpur district out of which Jashpur block was selected by purposive sampling for the study. There were 92 villages in the selected block out of which 3 villages were selected purposively on the basis that most area were engaged in tea gardening.

The villages that were selected are Sarudih, Sogada and Kantabel. A total of 120 respondents were selected randomly. The structured interview schedule was prepared for data collection. Descriptive research design was used for this study. The statistical tools such as frequency, ranking and percent were used to interpret the data and for drawing logical conclusion. 
Prerna Kujur et al, International Journal of Advances in Agricultural Science and Technology, Vol.8 Issue.9, September-2021, pg. 9-14

ISSN: 2348-1358 Impact Factor: 6.057 NAAS Rating: $\mathbf{3 . 7 7}$

\section{RESULTS AND DISCUSSION}

Table 1: Socio-economic profile of the respondents: $n=120$

\begin{tabular}{|c|c|c|c|c|}
\hline S. No. & $\begin{array}{l}\text { Independent } \\
\text { Variables }\end{array}$ & Category & Frequency & Percentage \\
\hline \multirow[t]{3}{*}{1.} & \multirow{3}{*}{ Age } & Young ( 20-35) & 32 & 26.67 \\
\hline & & Middle (35-55) & 67 & 55.83 \\
\hline & & Old (Above 55) & 21 & 17.50 \\
\hline \multirow[t]{6}{*}{2.} & \multirow{6}{*}{ Education } & Primary School & 38 & 31.67 \\
\hline & & Middle School & 24 & 20.00 \\
\hline & & High School & 20 & 16.66 \\
\hline & & Higher Secondary & 12 & 10.00 \\
\hline & & Graduation/PG/Diploma & 6 & 05.00 \\
\hline & & Illiterate & 20 & 16.67 \\
\hline \multirow[t]{3}{*}{3.} & \multirow{3}{*}{ Land Holding } & Below 1 acre & 23 & 19.16 \\
\hline & & $1-3$ acre & 69 & 57.50 \\
\hline & & Above 3 acre & 28 & 23.30 \\
\hline \multirow[t]{3}{*}{4.} & \multirow{3}{*}{ Annual Income } & Up to Rs 40,000 & 12 & 10.00 \\
\hline & & $40,001-80,000$ & 81 & 67.50 \\
\hline & & Above 80,000 & 27 & 22.50 \\
\hline
\end{tabular}




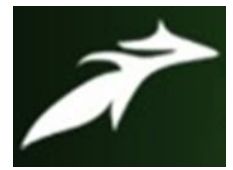

Prerna Kujur et al, International Journal of Advances in Agricultural Science and Technology, Vol.8 Issue.9, September-2021, pg. 9-14

ISSN: 2348-1358 Impact Factor: 6.057 NAAS Rating: 3.77

\begin{tabular}{|c|c|c|c|c|}
\hline \multirow[t]{3}{*}{5.} & \multirow{3}{*}{ Family Type } & Nuclear & 76 & 63.30 \\
\hline & & Joint & 33 & 27.50 \\
\hline & & Extended & 11 & 09.10 \\
\hline \multirow[t]{3}{*}{6.} & \multirow[t]{3}{*}{ Mass Media Exposure } & High (8.4-10) & 34 & 28.33 \\
\hline & & Medium (6.7-8.3) & 58 & 40.00 \\
\hline & & Low (8.4- 10) & 28 & 23.33 \\
\hline \multirow[t]{3}{*}{7.} & \multirow[t]{3}{*}{ Extension Contact } & High (9.2-12) & 49 & 40.83 \\
\hline & & Medium (6.1-9.1) & 50 & 41.67 \\
\hline & & Low (3-6) & 21 & 17.50 \\
\hline
\end{tabular}

From the data mentioned in table 1, it is found that 55.83 of the respondents are of the middle aged category i.e. age group of 20-35 years, 31.67 percent of the respondents attained primary education, 57.5 per cent of respondents possess 1-3 acre of land, annual income of 67.5 per cent respondents was in range of Rs. 40,001-Rs. 80,000 , family type of $63.3 \%$ of respondents were nuclear, $40 \%$ of the respondents have medium level of mass media exposure and 41.67 per cent of respondents have high medium of extension contact.

Constraints faced by tea garden women respondents working in tea garden

\begin{tabular}{|l|l|l|l|l|}
\hline S. No. & Constraints & Frequency & Percentage & Rank \\
\hline 1. & Sanitation facilities & 89 & 74.16 & I \\
\hline 2. & Distance from home & 75 & 62.50 & III \\
\hline 3. & Medical facilities & 68 & 56.67 & V \\
\hline
\end{tabular}




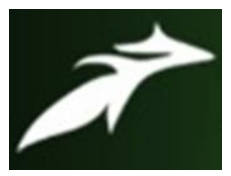

Prerna Kujur et al, International Journal of Advances in Agricultural Science and Technology, Vol.8 Issue.9, September-2021, pg. 9-14

ISSN: 2348-1358

Impact Factor: 6.057

NAAS Rating: 3.77

\begin{tabular}{|l|l|l|l|l|}
\hline 4. & Wage & 45 & 37.50 & IX \\
\hline 5. & Safety measures & 54 & 45.00 & VI \\
\hline 6. & Availability of rest time & 48 & 40.00 & VIII \\
\hline 7. & Overtime allowance & 85 & 70.83 & II \\
\hline 8. & Facilities in emergency & 36 & 30.00 & X \\
\hline 9. & Bonus facilities & 73 & 60.83 & IV \\
\hline 10. & Child care facilities & 49 & 40.83 & VII \\
\hline
\end{tabular}

From the above mentioned data it is concluded that majority of the respondents found sanitation facilities as the major constraint with the frequency 89 and 74 per cent, followed by the overtime allowance with frequency $85,70.83$ per cent and distance of the tea garden from their home with the frequency 75 and 62.5 per cent bonus facilities with frequency 73. 68 respondents felt the need of medical facilities having $56.67 \%$, followed by the constraints as safety measures with the frequency 54 and $45 \%$, availability of rest time with frequency 48 and 40 per cent, facilities in emergency with frequency 36,30 percent and childcare facilities with the frequency 49 and 40.83 per cent.

\section{REFERENCES}

[1]. Afzal F. (2019): Socio- Economic Condition of Tea Garden respondents in North Bengal, India “, Social and Economic Development of India" Edition first, Chapter 16.

[2]. Ahmed M., Begum A. \& Chowdhury, M.A.I. (2009, April 14). Social constraints before sanitation improvement in tea gardens of Sylhet Bangladesh. EnvironMonit Assess. Doi:10.1007/s10661-009-0890-0.Epub2009 Apr 14. PMID: 19365608.

[3]. Akhtar P, "Need of education among the tea tribe women in the Udalguri district of Assam India", The Clanon, Volume 2, Number 1, 2013, PP 167-173.

[4]. Anoop, R.J. 2013. Social exclusion of tribal agricultural labourers: The case of Paniya tribe of Wayanad. M.Sc. (Ag.) thesis, Kerala Agricultural University, Thrissur, 83p.

[5]. Ansari S. and Zebasheereen, "Socio-economic condition of tea garden worker in Alipurduar district West Bengal", IJRSS, Volume 6, Issue 2, Feb 2016, PP 493-503 


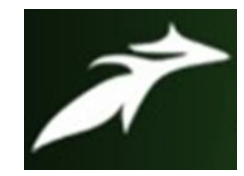

Prerna Kujur et al, International Journal of Advances in Agricultural Science and Technology, Vol.8 Issue.9, September-2021, pg. 9-14

ISSN: 2348-1358

Impact Factor: 6.057

NAAS Rating: 3.77

[6]. Arya N. (2013). Indian Tea Scenario. International Journal of Scientific and Research Publications, 3 (7), P. 1-10.

[7]. Beck, R.R.(2007). Condition of Workers in Closed Tea Gardens: A Report on Jalpaiguri District of West Bengal.

[8]. Borah N. (2013). The rights of women respondents in the tea gardens of Assam. The Clarion, 2 (2), ). 128-131.

[9]. Choudhary B. (2020) "Addressing Gender-Based Violence in tea gardens in Assam, India"

[10].Das R. K. (2019) "Chhattisgarh promoting tea cultivation in northern belt"

[11].Debnath P. (2017) "International Journal of Humanities \& Social Science Studies” ISSN: 23496711, Volume-4, Issue-1, July 2017, Page no. 248-261.

[12].Devi P.(2014), "Socio economic status of the tea garden women respondents in Assam" a case study with special reference to Sonitpur district, Reviews of Literature Impact Factor: 1.4716(UIF) Volume 2, Issue 2/Sept 2014.

[13].Hariharan, N.P. and Kumar, S.S. (2014) A study on the economic status of workers in large tea estates with special reference to the Nilgiris district of Tamil Nadu in India. Int. J. Appl. Business Econ. Res. 12(3): 717-727.

[14].Hazarika K. (2012), "Tea Tribes are lagging behind in the Process of Urbanization", International Journal of Trends in Economics Management and Technology, Volume 1, Issue 6, pp. 2-6.

[15].Kaushal, H. (2008) A networking approach to avert farmers' suicides Agric. News. 95(1): 255-259.

[16].Philips, A. (2010) Rethinking culture and development: marriage and gender among the tea plantation workers in Sri Lanka. J. Gender Dev. 11(2): 20-29.

[17].Prabhu, C.I. (2011) Aspiration of educated unemployed youth for self-employment in agriculture and allied fields. M.Sc. (Ag.) thesis, Kerala Agricultural University, Thrissur, 151p.

[18].Purkayastha, $\mathbf{N}$ and Kalita, P. (2016) Tea garden labourer and ther living condition: A study in Borsillah tea estate of Sivsagar district, Assam. Int. J. Adv. Res. 4(10): 163-169. Saikie S. , Misra S. and Misra B (2015) “ The Garden Labours and Their Living conditions: A study on Sasurai Tea Garden of Johart District of Assam” Research Paper.

[19].Roy S. (2015). "Modernization of Crisis? Tea Gardens of West Bengal in the Age of Media and Communication", Journal of content community and communication. Vol.1.Year 1. pp.7-13 ISSN No.23957514

[20].Sarkar S. C. (2013), "The Condition of Tea Garden respondents of Jalpaiguri District in Colonial India", International Journal of Advance Research, IJOAR. Org, Volume 1, Issue 8, ISSN 23209151, pp. 14-25.

[21].Shincy, N.I. 2012. Livelihood analysis of Irula tribe of Attappady. M.Sc. (Ag) thesis, Kerala Agricultural University, Thrissur,, 120p. 